\title{
Congressional Intent and Deference to Agency Interpretations of Regulations
}

\author{
Melanie E. Walker†
}

Increasingly, Congress transfers responsibility for implementing regulatory programs from one administrative agency to another. The new agency often must interpret regulations promulgated by its predecessor. Suppose a regulation is ambiguous. Presumably, the agency that drafted the regulation can better reconstruct its intended meaning. Thus, a court seeking the "correct" interpretation may defer to the drafting agency. Congress, however, has delegated the policymaking authority necessary for implementing the regulatory program to the transferee agency, and for this reason a court may defer to it.

Current case law suggests two alternative reasons for deference to agency interpretations of regulations. The Supreme Court originally held that courts should defer to agency interpretations for practical reasons: an agency, as author of the regulation, is more competent than the judiciary to find its intended meaning and has a better understanding of how different interpretations can affect outcomes and policy goals. The second reason for deference to agency interpretations rests on a delegation rationale and stems from Chevron USA, Inc v Natural Resources Defense Council. ${ }^{1}$ In Chevron, the Court justified deference to agency interpretations of ambiguous statutes on the grounds that Congress had delegated to the agency the power to fill in statutory ambiguities. ${ }^{2}$ Although many courts have invoked Chevron to justify deferring to agency interpretations of regulations, the Supreme Court has made no explicit pronouncement that Chevron's delegation rationale subsumed the Court's prior reasoning in the context of agency regulations.

In most cases, a court's justification for deference may seem inconsequential to the outcome. ${ }^{3}$ Either way, an agency's inter-

$\dagger$ B.A. 1996, Reed College; J.D. Candidate 2000, The University of Chicago.

1467 US 837 (1984).

2 Id at 843-44.

${ }^{3}$ See Paralyzed Veterans of America v DC Arena LP, 117 F3d 579, 584 (DC Cir 1997) ("It would seem that there are few, if any, cases in which the standard applicable under Cheuron would yield a different result than the 'plainly erroneous or inconsistent' standard set forth [for deference to agency interpretations of regulations] in Bowles v. Seminole Rock \& Sand Co."). 
pretation, if reasonable, will be adopted by the court. However, as seen in the example above, and in other cases where two agencies assert conflicting interpretations of a regulation, the court must choose between agencies. In these situations, the underlying justification for deference may change the outcome of the case. In other words, in cases where agencies espouse different interpretations of the same regulation, a court relying on the Cheuron delegation rationale may defer to a different agency's interpretation than it would under the previous doctrine.

This Comment argues that just as Chevron revolutionized deference to agency interpretations of statutes, Cheuron should control courts' deference to agency interpretations of regulations. That is, a court's deference to an agency interpretation of a regulation should be based on a delegation rationale: when Congress delegates rulemaking authority to an administrative agency, it intends the agency's authority to include making reasonable policy choices in interpreting the regulations promulgated under that authority. Using the Chevron framework, the Comment concludes that when conflicts arise under the split enforcement model-that is, where rulemaking and adjudicatory functions under one statute are split between two independent agenciescourts should defer to the agency to which Congress has delegated lawmaking power. If jurisdiction is transferred from one agency to another, courts should defer to the latter, as the transfer itself may indicate a congressional determination that the transferee agency will make policy choices more in line with congressional intent. When agencies share jurisdiction, it might be appropriate for the agencies to have different interpretations given their different spheres of expertise and presumed delegated policymaking authority within those spheres. A court rarely will need to determine the controlling interpretation of the regulation when it relies on a presumption of delegated interpretive authority.

Part I of this Comment outlines the evolution of the Supreme Court's justifications for deference to agency interpretations. Part II argues that the Court's more recent pronouncement that courts should "presume that the power authoritatively to interpret its own regulations is a component of the agency's delegated lawmaking powers"4 should be uniformly adopted, and then responds to possible criticisms of this approach. Part III illustrates how a court's analysis in cases involving interagency disputes should

- Martin v Occupational Safety and Health Review Commission, 499 US 144, 151 (1991). 
proceed given the adoption of the presumption outlined in Part II. In particular, Part III examines disputes that arise when rulemaking authority and adjudicatory authority are split between two agencies, when jurisdiction over a statute has been transferred from one agency to another, and when agencies have overlapping jurisdiction.

\section{THE JUSTIFICATIONS FOR DEFERENCE}

\section{A. Pre-Chevron Justifications for Judicial Deference to Agency Interpretations of Statutes and Regulations ${ }^{5}$}

Initially, the Supreme Court accorded a similar level of deference to an agency's interpretations of its own regulations as to interpretations of its organic statutes. ${ }^{6}$ The Court reasoned that an agency's interpretation of the statute it is charged with administering deserves respect because "[e]veryday experience in the administration of the statute gives [the agency] familiarity with the circumstances." Agency interpretations of statutes were

s Some preliminary explanations are in order. Agency interpretations can be either issued through "interpretive rules" or "legislative rules." The term "interpretive rule" can be found in the Administrative Procedures Act ("APA"), 5 USC $\S$ 553(b)(3)(A) (1994). The term "legislative rules" does not appear in the APA, but is commonly used among courts and scholars. See Robert A. Anthony, "Interpretive" Rules, "Legislative" Rules and "Spurious" Rules: Lifting the Smog, 8 Admin L J Am U 1, 2 (1994). Legislative rules are those that have been promulgated pursuant to statutory lawmaking authority and in accordance with the procedures set forth in Sections 553, 556, and 557 of the APA. They have the force of law. Id. Interpretive rules are any rules issued without exercising delegated lawmaking authority. They are not subject to the procedural requirements of the APA and are not binding on courts. See 5 USC $\$ 553$ (1994) (exempting interpretive rules from the procedures set forth in that section) and Kenneth Davis, 2 Administrative Law Treatise 36, 51-52. Interpretive rules are meant to explain how an agency understands the statute, not add to the substantive law. See Anthony, 8 Admin L J Am U at 13. Agency interpretations of their own regulations (these regulations themselves being legislative rules) are considered interpretive rules. Agency interpretations of statutes may be either legislative rules or interpretive rules, depending on whether the agency is exercising delegated lawmaking authority. Deciding in any particular case whether an agency is exercising delegated lawmaking authority may be difficult, but that issue is beyond the scope of this discussion. For more on this point, see Stephen G. Breyer, et al, Administrative Law and Regulatory Policy 247-48 (Aspen 4th ed 1998), and Anthony, 8 Admin L J Am U 1. Unless indicated otherwise, the agency interpretations of statutes discussed herein were promulgated through legislative rules.

6 See, for example, International Brotherhood of Teamsters, Chauffeurs, Warehousemen and Helpers of America $v$ Daniel, 439 US 551, $566 \mathrm{n} 20$ (1979) ("It is commonplace in our jurisprudence that an administrative agency's consistent, longstanding interpretation of the statute under which it operates is entitled to considerable weight.") (citations omitted); United States $v$ Larionoff, 431 US 864, 872 (1977) ("In construing administrative regulations, "the ultimate criterion is the administrative interpretation, which becomes of controlling weight unless it is plainly erroneous or inconsistent with the regulation."), quoting Bowles v Seminole Rock \& Sand Co, 325 US 410, 414 (1945).

' NLRB v Hearst Publications, 322 US 111, 130 (1944). 
not controlling-it was still the duty of a court to resolve questions of statutory interpretation-but were considered persuasive because of the agency's experience with its organic statutes. ${ }^{8}$

The Court has found an agency's interpretations of its own regulations similarly persuasive. ${ }^{9}$ The Court first adopted this position in Bowles $v$ Seminole Rock \& Sand $\mathrm{Co}^{10}$ where it held that the Administrator of the Office of Price Administration's interpretation of a maximum price regulation issued under the Emergency Price Control Act was "of controlling weight unless it [was] plainly erroneous or inconsistent with the regulation."11 Finding that the agency's interpretation was reasonable and consistently applied, the Court enforced the regulation as interpreted by the agency. ${ }^{12}$ The Court gave no explicit justification for granting such weight to the Administrator's interpretation, but stated that his interpretations were "tools" for discovering the meaning of the price regulation. ${ }^{13}$ Nothing in the Act itself suggested that Congress intended the Administrator's interpretations to be controlling. ${ }^{14}$

Subsequent lower court decisions applying Seminole Rock to other agency interpretations of regulations gave content to the deference rationale. One court explained that " $t]$ he primary ra-

- Id at 130-31 (Undoubtedly questions of statutory interpretation, especially when arising in the first instance in judicial proceedings, are for the courts to resolve, giving appropriate weight to the judgment of those whose special duty is to administer the questioned statute."). See also Antonin Scalia, Judicial Deference to Administrative Interpretations of Law, 1989 Duke L J 511, 514:

The cases, old and new, that accept administrative interpretations, often refer to the 'expertise' of the agencies in question, their intense familiarity with the history and purposes of the legislation at issue, their practical knowledge of what will best effectuate those purposes. In other words, they are more likely than courts to reach the correct result.

9 Agency interpretations of regulations are set forth in interpretive rules, which are exempt from the notice and comment requirements of the APA. See 5 USC $\S 553(b)(3)(A)$. See text accompanying notes 79-81 for discussion of possible implications of this exemption.

${ }^{10} 325$ US 410 (1945).

"Id at 414 .

12 Id at 417-18.

${ }^{13}$ Id at 414.

14 Emergency Price Control Act of 1942, Pub L No 420, 56 Stat 23, codified at 50 App USC § 924 (1984), 50 USCA § 902(a), repealed by Pub L No 89-554, § 8(a), 80 Stat 651 (1966). Some statutes do explicitly provide that an agency's interpretation of an act or regulation issued thereunder is authoritative. See Ford Motor Credit Co $v$ Milhollin, 444 US 555, 567-58 (1980) (finding that a Truth in Lending Act ("THA") amendment that provides creditors with a defense from liability based on good-faith compliance with a rule, regulation, or interpretation of the Federal Reserve Board "signals an unmistakable congressional decision to treat administrative rulemaking and interpretation under TILA as authoritative"). 
tionale behind the doctrine of deference is recognition of administrative expertise developed through implementation and enforcement of statutes and regulations." ${ }^{\prime 3}$ An agency's interpretations of the regulations it had promulgated were considered even more persuasive than agency interpretations of statutes. ${ }^{16} \mathrm{Be}$ cause the agency drafted the regulation, courts presumed that the agency not only had superior expertise developed through implementing the regulation, but also greater knowledge of the regulation's intended meaning. ${ }^{17}$

Thus, prior to Chevron, the same reasoning underlay deference to an agency's interpretations of its own regulations and an agency's interpretations of its organic statutes. Because agency administrators have more experience than courts in implementing the statute or regulation and greater familiarity with circumstances surrounding the regulatory program, the agency's interpretation is more likely to be "correct." 18 The agency's interpretation, therefore, has persuasive force.

Under Seminole Rock, if a court is faced with conflicting agency interpretations of the same regulation, either the court could determine the correct interpretation independently-since neither agency interpretation is controlling-or it could attempt to determine which agency has superior experience and expertise. In most, if not all, cases, the drafting agency's presumed superior

${ }^{15}$ Standard Oil Co v Department of Energy, 596 F2d 1029, 1055-56 (Temp Emer Ct 1978) (holding that the agency should not be deferred to, because the agency's interpretation of the regulation was not in effect during the relevant period). Accord Milhollin, 444 US at $566 \mathrm{n} 9$ (indicating that deference to administrative views is based, at least partially, on respect for agency expertise). Professor Manning argues that the Court did not supply a rationale for Seminole Rock deference to agency interpretations of regulations until its decision in Pauley $v$ BethEnergy Mines, Inc, 501 US 680 (1991), at which time it "incorporated Cheuron's more fully developed premises." John F. Manning, Constitutional Structure and Judicial Deference to Agency Interpretations of Agency Rules, 96 Colum L Rev 612, 619 (1996), citing Pauley, 501 US at 696-97. However, Professor Manning appears to downplay the Court's previous language mentioning agency expertise in these cases.

${ }^{16}$ See Russell L. Weaver and Thomas A. Schweitzer, Deference to Agency Interpretations of Regulations: A Post-Chevron Assessment, 22 Memphis St U L Rev 411, 418-19 (1992) (observing that prior to Chevron, the Court viewed deference as even more appropriate when a court was confronted with an agency's interpretation of its own regulation rather than an agency's interpretation of a statute), citing Udall $v$ Tallman, 380 US 1, 16 (1965).

${ }^{17}$ See, for example, Stinson $v$ United States, 508 US 36, 45 (1993) (stating that since the Sentencing Commission drafts the commentary to the Sentencing Guidelines "we can presume that the interpretations of the guidelines contained in the commentary represent the most accurate indications of how the Commission deems that the guidelines should be applied").

${ }^{13}$ The idea that a court might choose to defer to agency interpretations of law because it thinks the agency's interpretation is presumptively correct is raised in Breyer, et al, Administrative Law and Regulatory Policy at 249 (cited in note 5). 
knowledge of the intent of the regulation would make its interpretation the most persuasive.

\section{B. Deference to Agency Interpretations of Statutes} After Chevron

Cheuron is one of the most widely discussed cases in the academic literature ${ }^{19}$ so the facts of the case will be given limited exposition here. The important point for this discussion is that in Chevron the Supreme Court supplied a stronger justification for deference to an agency's interpretations of its organic statutes. In short, the Court reasoned that courts should defer because, when a statute is silent or ambiguous, Congress has delegated the policymaking authority necessary to fill the gap to the agency charged with implementing the statute. ${ }^{20}$

The Court developed a two step analysis for cases involving agency interpretations of statutes. First, the court asks whether Congress has directly spoken on the question at issue. If so, Congress's statement is controlling. ${ }^{21}$ Second, if there is no clear congressional intent-that is, if the statute is silent or ambiguous on the question-the court asks whether the agency's interpretation is "based on a permissible construction of the statute."22 If the agency's interpretation is reasonable, it is controlling, even if the court itself would have chosen a different interpretation. ${ }^{23}$

The Court justified deferring to the agency's interpretation in this second step by presuming that when Congress fails to specifically address a given issue in a regulatory scheme,${ }^{24}$ it intends the agency to whom it has delegated policymaking authority to use that authority to "fill the gap." 25 Commentators have explained that this presumption is based on the Court's rational reconstruction of congressional instructions. ${ }^{26}$ Because Congress

${ }^{19}$ A search of the Westlaw database on August 10, 1999 revealed 2,912 secondary source citations to Chevron.

20 Cheuron, 467 US at 843.

${ }^{21}$ Id at 842 .

2 Id at 843 .

2 Id (stating that the court does not impose its own construction of the statute); id at 844 (holding that the agency's interpretation is to be given "controlling weight unless [it is] arbitrary, capricious, or manifestly contrary to the statute").

${ }^{24}$ Id at 865 (noting that Congress may have "desired the Administrator to strike the balance at this level," may not have considered the issue, or may not have been able "to forge a coalition on either side of the question").

${ }^{25}$ Id at 843-44.

${ }^{26}$ See Manning, 96 Colum L Rev at 617 (cited in note 15) ("Chevron categorically presumes that Congress has opted for implementation of the statutory mandate by the more politically accountable administrative agency, and not the less accountable reviewing court."); Cass R. Sunstein, Law and Administration after Chevron, 90 Colum L Rev 2071, 
has instructed the agency to make all policy choices within its sphere of delegated authority, the agency's policy choices are not merely persuasive to courts, but authoritative. ${ }^{27}$

The Court went on to set forth several reasons why Congress delegates this authority to an agency; in other words, why it is reasonable for courts to presume that Congress intends for agencies to "fill the gaps" it leaves. The Court noted that agencies have greater political accountability than courts, ${ }^{28}$ are often in a better position than the legislature to make difficult political choices, ${ }^{29}$ and have greater expertise than courts and the legislature in administering often "technical and complex" regulatory schemes..$^{30}$ Thus, the notion of superior agency expertise that the Court originally had used to justify deference to agency interpretations of statutes still played some role in Cheuron. ${ }^{31}$ In many cases, one of the primary reasons Congress has delegated rulemaking authority to the agency is because of the administrators' technical expertise and experience. Hence, notions of expertise often guide the court in determining congressional intent.

The important difference between Chevron and Seminole Rock is that under Chevron, intent, and not expertise, is ultimately the determinative factor. Under Seminole Rock, the court defers for practical reasons only. There is no operating presumption that Congress intended the agency to have interpretive authority. At this point, the distinction between Seminole Rock deference-to-expertise and Cheuron deference-to-legislative-intent

2101 (1990) ("Chevron's principle of deference, then, is an attempted reconstruction of congressional instructions, one that is responsive to the comparative advantages of the agency in administering complex statutes."); Scalia, 1989 Duke L J at 516 (cited in note 8) ("Chevron ... replaced this statute-by-statute evaluation ... with an across-the-board presumption that, in the case of ambiguity, agency discretion is meant."). Compare Thomas W. Merrill, Judicial Deference to Executive Precedent, 101 Yale L J 969, 995 (1992) (arguing that there is, at best, weak evidence to support the presumption that when Congress delegates authority to administer a statute to an agency, Congress wants courts to defer to that agency's interpretation of law).

${ }^{27}$ See Manning, 96 Colum L Rev at 622-23 (cited in note 15) ("When a statute merely confers authority upon an agency, a reviewing court interprets the statute by determining the scope of the authority assigned. . . . If a court refuses to accept (defer to) the agency's reasonable interpretation of that term ... it usurps the norm-elaboration responsibility that Congress has committed to the agency's 'judgment.").

3* Cheuron, 467 US at 865 ("While agencies are not directly accountable to the people, the Chief Executive is, and it is entirely appropriate for this political branch of the government to make such policy choices.").

29 Id (noting that Congress may have left the question to the agency because it was "unable to forge a coalition on either side of the question").

${ }^{\infty}$ Id.

"Id (noting that the EPA's decision required expertise in a "technical and complex" regulatory scheme). 
may seem like a distinction without a difference. Part III shows how this distinction affects the outcome in some cases.

Cheuron itself does not explicitly override Seminole Rock: the holding in Cheuron only reaches an agency's interpretations of its organic statute. Part II discusses whether the Chevron holding should reach agency interpretations of their own regulationsthat is, whether agencies are exercising delegated authority when they interpret regulations they have promulgated. That Part also argues that the nuanced distinction between Seminole Rock deference and Cheuron deference has important constitutional implications.

In the context of interagency conflict, it follows from Chevron that if a court is faced with conflicting interpretations of a statute set forth by two agencies, the interpretation of the agency to whom Congress has granted rulemaking authority-that is, the agency with policymaking authority-would be controlling. ${ }^{32}$

\section{Deference to Agency Interpretations of Regulations After Chevron}

The underlying justifications for deference to agency interpretations of regulations and agency interpretations of statutes were the same before Cheuron was decided $;^{33}$ afterward, however, it was unclear whether Chevron also applied to an agency's interpretations of its own regulations. ${ }^{34}$

Several lower courts have cited to Chevron when deferring to agency interpretations of their own regulations..$^{35}$ For example, in Pope $v$ Shalala, ${ }^{36}$ the Seventh Circuit, citing Chevron, insisted

\footnotetext{
${ }^{32}$ Part I.C addresses which agency's interpretation would be controlling when two agencies set forth conflicting interpretations of a regulation, if a court adopts the justification for deference laid out in Cheuron.

${ }^{33}$ See Part I.A.

" See Weaver and Schweitzer, 22 Memphis St U L Rev at 411-13 (cited in note 16) (observing that, in light of its "revolution[ary]" effect on deference principles, "it is quite possible that Cheuron affected the Courts approach to agency interpretations of regulations").

${ }^{35}$ See Foothill Presbyterian Hospital v Shalala, 152 F3d 1132, 1134 (9th Cir 1998) ("If a statute or regulation is silent or ambiguous, we will defer to the agency's interpretation."); Paralyzed Veterans of America v DC Arena LP, 117 F3d 579, 585 (DC Cir 1997) ('Under Chevron, an agency's interpretation of ambiguous statutory language is entitled to deference because of the agency's delegated authority to administer the statute, and the same consideration underlies deference to an agency's interpretation of its own regulations."); Pope $v$ Shalala, 998 F2d 473, 485-86 (7th Cir 1993) ("When the ambiguous rule falls within an agency's congressionally delegated authority, it is the chosen policymaker, and the agency, not the courts, which must select among conflicting interpretations of the rule .... This deference is especially appropriate when we are faced with an agency's interpretation of its own regulation.").

${ }^{36} 998$ F2d 473 (7th Cir 1993).
} 
that resolving ambiguities in legal rules-whether they be statutes or regulations-is a component of an agency's delegated policymaking authority and that courts may not substitute their own policy judgments for the one made by the administrator. ${ }^{37}$ The Ninth Circuit has applied the Cheuron two-step analysis to agency interpretations of regulations, suggesting that the same reasons underlie deference both to interpretations of statutes and regulations. ${ }^{38}$

The D.C. Circuit has also maintained that courts should defer to agency interpretations of regulations based on a Chevron delegation rationale. ${ }^{39}$ Recently, in Paralyzed Veterans of America $v D C$ Arena $L P^{40}$ the court offered its most thorough explanation of this position. Paralyzed Veterans concerned the proper interpretation of a regulation issued under the Americans with Disabilities Act stating that wheelchair seating areas in arenas must have "lines of sight comparable to those for members of the general public." ${ }^{41}$ The Department of Justice interpreted "lines of sight comparable" to require sightlines over standing spectators. ${ }^{42}$ The Arena argued that the court should not defer to the DOJ's interpretation because although the DOJ promulgated the regulation, it did not draft it. ${ }^{43}$ Thus, the DOJ did not have greater knowledge of the original intent of the regulation than the court. ${ }^{44}$

The court rejected the Arena's argument on the ground that deference to an agency's interpretations of its own regulations is not based on the agency's drafting expertise, but on congressional delegation of authority to reconcile regulatory ambiguities. ${ }^{45}$ The court reasoned:

${ }^{37}$ Id at 485 .

${ }^{33}$ Foothill Presbyterian, 152 F3d at 1134 (summarizing Chevron two-step test).

See Paralyzed Veterans, 117 F3d at 585; Amerada Hess Pipeline Corp v FERC, 117 F3d 596, 601 (DC Cir 1997) ("D]eference is not accorded to agency interpretations [of regulations] merely because they possess a special expertise. Courts defer to agency interpretations in large part because Congress has chosen to delegate to the agency decisionmaking in the field."); Caiola $v$ Carroll, 851 F2d 395, 399 (DC Cir 1988) (citing Chevron for the proposition that "[i]t is axiomatic that an agency's interpretation of its own regulations is entitled to considerable deference").

117 F3d 579 (DC Cir 1997).

"Id at 581 .

12 Id at 582. The DOJ's interpretation was promulgated in a supplement to its Americans with Disabilities Act Title III Technical Assistance Manual.

43 Id at 581 (noting that the regulation was drafted by the Architectural and Transportation Barriers Compliance Board). The Justice Department has rulemaking authority for Title III of the Americans with Disabilities Act. See id at 580, citing 42 USC § 12186(b).

" 117 F3d at 585.

4 Id. 
Under Chevron, an agency's interpretation of ambiguous statutory language is entitled to deference because of the agency's delegated authority to administer the statute, and the same consideration underlies deference to an agency's interpretation of its own regulation. The resolution of ambiguities in a regulation implicates the same sort of policy choices it does with regard to a statute. ${ }^{46}$

Thus, according to the D.C. Circuit, the same justification underlying Cheuron deference supports judicial deference to agency interpretations of regulations they have promulgated.

The Supreme Court has not explicitly addressed the question whether the Chevron delegation rationale applies to agency interpretations of their own regulations. Moreover, language on this point in two recent Court opinions seems to conflict. ${ }^{47}$ In Stinson $v$ United States, ${ }^{48}$ the Court determined the extent to which the commentary to the Sentencing Guidelines controls federal courts' interpretations of the Guidelines, by analogizing it to agency regulations. ${ }^{49}$ The Court explained that the commentary is more analogous to an agency's interpretation of its own regulations than to an agency's construction of a federal statute that it administers. Therefore, the Court held that the Seminole Rock standard of "controlling weight," and not Cheuron deference, applied..$^{50}$

Stinson sheds light on the then-perceived differences between the rationales underlying deference to agency interpretations of regulations and agency interpretations of statutes. The Court reasoned that

[c]ommentary, unlike a legislative rule, is not the product of delegated authority for rulemaking, which of course must yield to the clear meaning of a statute. Rather, commentary explains the guidelines and provides concrete guidance as to how even unambiguous guidelines are to be applied in practice. ${ }^{51}$

${ }^{46}$ Id (citations omitted).

${ }^{47}$ See Stinson, 508 US at 36, and Martin v Occupational Safety and Health Review Commission, 499 US 144, 144 (1991), discussed at length below in text accompanying notes 57-61.

${ }^{43} 508$ US 36 (1993). See id at 38 (holding that the commentary in Sentencing Guidelines is binding unless it violates the Constitution or a federal statute or is inconsistent with, or a plainly erroneous reading of, a guideline).

${ }^{49}$ Id at 45.

${ }^{50}$ Id at 44-45.

${ }^{31}$ Id at 44 (internal citations omitted). 
The purpose of the commentary is to "assist in the interpretation and application" of the Guidelines. ${ }^{52}$ The Court emphasized that deference was due to the Commission because it "drafts the guidelines as well as the commentary interpreting them."

In contrast, had the Court found Cheuron controlling, courts would have been required to yield to the commentary only if a guideline was ambiguous and then only if it was a "permissible construction" of the guideline in question. ${ }^{54}$ Much of the commentary addressed unambiguous guidelines. ${ }^{55}$ Therefore, if the Court had applied Chevron, much of the commentary would not have been held binding on federal courts. ${ }^{56}$ The important lesson of Stinson, however, is that the Court did not use Chevron to supplant Seminole Rock; instead, it continued to use the Seminole Rock justification for deference by appealing to the Commission's drafting role and expertise.

Arguably, however, the reasoning in Stinson should be limited to the facts presented since the Court was deciding the legal force of commentary to the Sentencing Guidelines, not agency interpretations of regulations. The Court's opinion in Martin v Occupational Safety and Health Review Commission, ${ }^{57}$ in which it appeared to adopt the Chevron delegation justification for deference to an agency's interpretation of its own regulations, is more directly on point.

In Martin, according to the Secretary of Labor's ("Secretary") interpretation of a regulation that she had promulgated under the Occupational Safety and Health Act ("Act"), CF \& I Corporation had violated that regulation. ${ }^{58}$ When the Occupational Safety

32 Id at 45.

s Id (adding that "we can presume that the interpretations of the guidelines contained in the commentary represent the most accurate indications of how the Commission deems that the guidelines should be applied to be consistent with the Guidelines manual as a whole as well as the authorizing statute").

st The difference in the standard of review courts give agency interpretations of statutes and agency interpretations of regulations is beyond the scope of this Comment. For a discussion of the varying standards courts have applied, see Weaver and Schweitzer, 22 Memphis St U L Rev at 414, 425-32 (cited in note 16). Weaver and Schweitzer argue that "in some post-Chevron decisions, the Court has actually used less deferential rhetoric than it used in pre-Cheuron decisions [regarding agency interpretations of regulations]." Id at 428. Interestingly, the Court in Stinson, going on to apply the Seminole Rock standard, held that the commentary is "binding" on courts and "authoritative," arguably stronger language than it had used in applying Seminole Rock in the past. Stinson, 508 US at 47. This may be attributable to changing views on the place of agency interpretations after Chevron or the unique status of the Sentencing Commission.

Stinson, 508 US at 44.

36 Id at 47.

${ }^{57} 499$ US 144 (1991).

${ }^{\text {ss }}$ Id at 148. 
and Health Review Commission ("Commission") reviewed the citation given to the corporation, however, it disagreed with the Secretary's interpretation of the regulation and held that the corporation was not in violation. ${ }^{59}$ In deciding whether the Secretary's or the Commission's interpretation controls in an enforcement hearing, the Court stated that

[b]ecause applying an agency's regulation to complex or changing circumstances calls upon the agency's unique expertise and policymaking prerogatives, we presume that the power authoritatively to interpret its own regulations is a component of the agency's delegated lawmaking powers. ${ }^{60}$

Because Congress granted rulemaking authority to the Secretary, her interpretation controlled. This is in sharp contrast to the Stinson Court's focus on drafting expertise and to the statement, quoted above, that the Sentencing Guidelines commentary is "not the product of delegated authority for rulemaking." ${ }^{\text {11 }}$

Subsequent Supreme Court cases involving agency interpretations of regulations suggest that the Court has adopted the position it set forth in Martin ${ }^{62}$ and has limited Stinson to cases involving the Sentencing Guidelines. ${ }^{63}$ Thus, the lower court and Supreme Court cases reveal a trend toward applying the principles enunciated in Cheuron to agency interpretations of their own regulations, although the D.C. Circuit is the only court that has clearly articulated why Chevron should be extended to regulations. Part II attempts to supply the needed justification for the view that agency interpretations of their own regulations merit deference because the interpretations are part of the agency's delegated authority. Part II also demonstrates that the view expressed by the Court in Martin-that agency interpretations of regulations merit deference because the interpretations are part of the agency's delegated authority-is a rational reconstruction of legislative intent and should guide courts in deciding other in-

\footnotetext{
${ }^{\infty}$ Id at 148-49.

${ }^{\infty}$ Id at 151. See also discussion of Martin in the context of interagency disputes in Part III.A.

${ }^{61}$ Stinson, 508 US at 44.

${ }^{62}$ See, for example, Shalala v Guernsey Memorial Hospital, 514 US 87, 94-95 (1995) (holding that the Secretary of Health and Human Services' interpretation of a regulation was reasonable and entitled to deference, citing Martin); Thomas Jefferson University $v$ Shalala, 512 US 504, 512 (1994) (holding that the Court "must give substantial deference to an agency's interpretation of its own regulations," citing Martin and Seminole Rock).

${ }^{63}$ See United States $v$ LaBonte, 520 US 751, 757 (1997); Neal v United States, 516 US 284, 293 (1996). The Supreme Court has only cited Stinson in one case involving an agency interpretation of a regulation. See Morse $v$ Republican Party of Virginia, 517 US 186, 201 (1996).
} 
teragency conflict cases. When deciding which agency interpretation to defer to, courts should look to which agency Congress has delegated "interpretive lawmaking power" under the statute in question. ${ }^{64}$

\section{CHEVRON DEFERENCE SHOULD BE APPLIED TO AGENCY INTERPRETATIONS OF REgULATIONS THEY HAVE PROMULGATED}

Part I suggests that there is a growing trend among courts to apply Chevron to agency interpretations of regulations based on the notion that an agency's interpretation of its regulations invokes congressionally delegated policymaking authority. This Part aims to clarify what it means to apply the Chevron justification for deference to cases involving the interpretation of an agency's own regulations. This Part will also substantiate the controversial view that an agency's power to interpret its own regulations is a component of the agency's delegated lawmaking powers and that courts should defer to agency interpretations for this reason.

\section{A. The Legitimacy of Applying Chevron Deference to Regulations}

1. Intent is a more constitutionally legitimate reason for deference than relative expertise.

Justice Scalia has argued in support of Chevron that if it is the constitutional duty of courts to "say what the law is," the Court must supply a valid theoretical justification for allowing agency interpretations to be controlling. ${ }^{65}$ While relative competence may be a good practical reason for deferring to agencies, it is not a sufficient constitutional justification for deference. Instead, deference can be justified as a means for courts to follow congressional intent ${ }^{66}$ - delegation of interpretive power to agencies. $^{67}$

\footnotetext{
${ }^{64}$ Martin, 499 US at 151 (discussing interpretive lawmaking power in the context of interpreting a regulation).

${ }^{\infty}$ Scalia, 1989 Duke L J at 514 (cited in note 8).

${ }^{66}$ Id at 516.

${ }^{67}$ It is essentially unquestioned today that Congress has broad power to delegate policymaking authority to agencies. See Touby $v$ United States, 500 US 160, 165 (1991) (We have long recognized that the nondelegation doctrine does not prevent Congress from seeking assistance, within proper limits, from its coordinate Branches. Thus, Congress does not violate the Constitution merely because it legislates in broad terms, leaving a certain degree of discretion to executive or judicial actors.") (internal citations omitted); Mistretta v United States, 488 US 361, 416 (1989) (Scalia dissenting) ("[W]e have almost never felt qualified to second-guess Congress regarding the permissible degree of policy
} 
Under Scalia's view, deferring to agency interpretations solely because of the agency's relative expertise, that is, because the court thinks the agency is more likely to reach the correct result, is constitutionally indefensible.$^{68}$ Because it is the constitutional duty of the courts to say what the law is, courts cannot abdicate this duty because they think the agency is more likely to get it right. ${ }^{69}$ As elucidated in Part $I,{ }^{70}$ deference under Seminole Rock is justified on precisely the relative expertise grounds that Scalia argues are theoretically invalid. In other words, the reasoning in Seminole Rock does not provide a constitutional basis for deferring to agency interpretations of their own regulations. The justification elucidated by Scalia for Cheuron-congressional intent-represents a more constitutionally legitimate basis for deference.

\section{Indications of congressional intent.}

There are strong indications that Congress intends agencies' poilicymaking authority to extend to the interpretation of their own regulations. Many of the factors cited in Chevron to support the presumption that Congress intends agencies rather than courts to fill the gaps left in statutes-greater political accountability, ability to reconcile competing political interests, and expertise in often complex and technical areas ${ }^{71}$-apply equally to agency interpretations of ambiguous regulations. Both tasks involve policymaking and in both contexts the agency is the congressionally chosen policymaker. However, Chevron involved an agency exercising rulemaking authority, which is often a large

judgment that can be left to those executing or applying the law. As the Court points out, we have invoked the doctrine of unconstitutional delegation to invalidate a law only twice in our history, over half a century ago.") (internal citations omitted). Chief Justice Rehnquist has unsuccessfully tried to revive the nondelegation doctrine. See American Textile Manufacturers Institute v Donovan, 452 US 490, 543 (1981) (Rehnquist dissenting), and Industrial Union Department, AFL-CIO v American Petroleum Institute, 448 US 607, 671, 688 (1980) (Rehnquist concurring in the judgment). This Comment assumes the legitimacy of the current approach to the nondelegation doctrine. But see American Trucking Associations, Inc $v$ United States Environmental Protection Agency, 175 F3d 1027 (DC Cir 1999) (striking down agency regulation partially on nondelegation grounds).

Cheuron itself has been attacked on numerous grounds, principally that it violates Marbury by giving agencies rather than courts the duty to say what the law is. See, for example, Merrill, 101 Yale L J 969 (cited in note 26). A defense of Cheuron, beyond the short explanation of Scalia's defense of it given above, is beyond the scope of this Comment. For other defenses of Cheuron, see Sunstein, 90 Colum L Rev 2071 (cited in note 26); Manning, 96 Colum L Rev at 621-27 (cited in note 15).

$\Leftrightarrow$ Scalia, 1989 Duke L J at 514 (cited in note 8).

${ }^{6} \mathrm{Id}$.

70 See Part I.A.

${ }^{7}$ See text accompanying notes 24-31. 
component of the agency's duties under the statute, and rulemaking is subject to different procedural requirements than agency interpretations of regulations. ${ }^{72}$ Therefore, further indications of congressional intent to delegate interpretive authority over regulations to agencies are needed.

Agency interpretations of regulations serve a unique function because they allow the rulemaker to clarify the meaning of the law without the need for judicial intervention. Section 553 of the APA provides strong evidence that Congress intends agencies to have great latitude in interpreting the regulations they have promulgated. Section 553 provides the "notice and comment" requirements for informal rulemaking, but exempts interpretive rules from these procedures. ${ }^{73}$ Agency interpretations of their own regulations are interpretive rules, since they do not create new substantive rights or obligations, but rather clarify what rights and obligations the regulation itself imposes. ${ }^{74}$

In discussing the role of interpretive rules, the D.C. Circuit held that

[t]he reading of the $\S 553$ exemptions that seems most consonant with Congress' purposes in adopting the APA is to construe them as an attempt to preserve agency flexibility in dealing with limited situations where substantive rights are not at stake. . . The function of $\S 553$ 's first exemption, that for 'interpretive rules,' is to allow agencies to explain ambiguous terms in legislative enactments without having to undertake cumbersome proceedings. ${ }^{75}$

Thus the exemption for interpretive rules serves to encourage agencies to clarify rules and provide further guidance to those regulated by the rules.

${ }^{72}$ See 5 USC $\S 553$ for the procedural requirements of informal rulemaking and 5 USC $\S \S 556-57$ (1994) for the procedural requirements for formal rulemaking.

${ }^{73} 5$ USC $\S 553(a)(3)$ (stating that the subsection does not apply to interpretive rules).

"4 "Interpretations" that do create new rights and obligations must be promulgated as new rules. See text accompanying notes 85-91. Courts are split on whether Chevron applies to interpretive rules that are interpretations of statutes. The discussion here suggests that the better view is that Cheuron should apply to interpretive rules across the board, although one could also argue that interpretative rules promulgated for regulations are distinguishable from interpretive rules promulgated for statutes since, with regulations, the agency is clarifying law it has drafted. Congress may intend courts to be more deferential to these clarifications, as noted in the discussion that follows.

${ }^{73}$ American Hospital Association v Bowen, 834 F2d 1037, 1045 (DC Cir 1987) (holding that regulations promulgated by HHS concerning Peer Review Organizations designed to oversee Medicare expenditures were exempt from notice and comment requirements as procedural rules or general statements of policy). 
More importantly, interpretations of regulations serve a special purpose. As the Court has stated, "Congress itself can eliminate a conflict [in the circuits] concerning a statutory provision by making a clarifying amendment to the statute, and agencies can do the same with respect to regulations." It is unlikely that Congress intends courts to override an agency's clarifying interpretive rule on the grounds that the court understood the regulation differently anymore than it intends courts to do the same to its own clarifying amendments. Thus a presumption that such interpretations are a component of an agency's delegated policymaking authority is a reasonable reconstruction of congressional instructions. As Judge Easterbrook has contended, in cases involving an agency's interpretation of its own regulation, it is clear that Congress has delegated to the agency full power to implement the regulation. ${ }^{77}$ In these cases, "judges leave policy-making to the policy-makers appointed by Congress."78 If Congress exempted interpretive rules from the procedural requirements of the APA to encourage agencies to promulgate them, it seems implausible that Congress would be in favor of strict judicial oversight of those rules.

B. Critiques of the Application and Responses to Them

1. Deference creates incentives to issue vague regulations.

Some commentators have argued against applying Chevron deference to agency interpretations of regulations because these interpretations, unlike agency interpretations of statutes, are not

${ }^{76}$ Pope, 998 F2d at 486, citing Braxton v United States, 500 US 344, 347-48 (1991).

${ }^{77}$ Homemakers North Shore, Inc $v$ Bowen, 832 F2d 408, 412 (7th Cir 1987) (treating interpretation by Secretary of HHS as nonsubstantive and, therefore, exempt from $\S 553$ requirements).

${ }^{78}$ Id. In Pauley, Justice Scalia, dissenting, argued that when authority for implementing a regulatory scheme has been transferred from one agency to another and the proper interpretation of a regulation is in dispute, the agency that drafted the regulation-not the transferee agency-deserves deference. Pauley $v$ BethEnergy Mines, Inc, 501 US 680, 707-08 (1991) (Scalia dissenting). The majority disagreed, holding that the transferee agency deserves deference because Congress has transferred all policymaking authority necessary for implementing the regulatory scheme to the new agency-including the authority to make policy choices in interpreting regulations. Id at 697 (majority opinion). See also discussion of Pauley in the text accompanying notes 111-16. Both the majority and Scalia agreed that the Court's Cheuron jurisprudence controlled-even though the case concerned the interpretation of a regulation. What they disagreed on was the best reconstruction of congressional intent in delegating interpretive authority. The discussion here supports the majority's position. It would follow from Justice Scalia's position that only the Congress that originally passed a bill is in a good position to pass a clarifying amendment. 
subject to the procedural safeguards of the APA. ${ }^{79}$ Deference in this context, the argument goes, creates incentives for agencies to issue vague regulations to which they later can give substance through "interpretations," ${ }^{\text {" the }}$ theby raising rule of law concerns, that is, concerns that the regulated will not know what rule or principle to follow. ${ }^{81}$ The initial regulation will be too vague to provide a meaningful guide and may be "interpreted" later to apply to conduct with no previous notice that such conduct would be considered a violation of the regulation.

The D.C. Circuit explicitly addressed the argument that Chevron deference will create incentives for agencies to issue vague regulations in Paralyzed Veterans. ${ }^{82}$ The court held that Section 553 of the APA prevents agencies from promulgating overly vague regulations:

A substantive regulation must have sufficient content and definitiveness as to be a meaningful exercise in agency lawmaking. It is certainly not open to an agency to promulgate mush and then give it concrete form only through subsequent less formal "interpretations." That technique would circumvent section 553, the notice and comment procedures of the APA. ${ }^{83}$

\footnotetext{
${ }^{79}$ Agency interpretations of statutes that are not promulgated pursuant to the agency's rulemaking authority are governed by the less deferential standard set forth in Skidmore v Swift, 323 US 134, 140 (1944) (holding that interpretive rules are not controlling upon the courts, but "do constitute a body of experience and informed judgment to which courts and litigants may properly resort for guidance" and setting forth the factors for courts to consider in determining what weight to give the interpretive ruling). Commentators arguing against the application of Chevron to an agency's interpretations of its own regulations claim that courts should give these interpretations the same degree of deference accorded to agency interpretations of regulations not promulgated pursuant to the agency's rulemaking authority - that is, the degree of deference outlined in Skidmore. In Skidmore, the Supreme Court held that interpretations not promulgated pursuant to an agency's rulemaking authority are not controlling, but may be considered by a court because of the agency's "experience and informed judgment." Id at 140.

${ }^{*}$ See Manning, 96 Colum L Rev at 655-57 (cited in note 15) (arguing that Seminole Rock deference gives agencies "the benefit of any doubt they have created" through vague regulations); Robert A Anthony, The Supreme Court and the APA: Sometimes They Just Don't Get It, 10 Admin L J Am U 1, 12 (1996) (arguing that deference to an agency's interpretations of its own regulations "generates incentives to be vague in framing regulations, with the plan of issuing 'interpretations' to create the intended new law without observance of notice and comment procedures").

${ }^{81}$ See Rule of law in Black's Law Dictionary 1332 (West 6th ed 1990) ('The rule of law, sometimes called 'the supremacy of law', provides that decisions should be made by the application of known principles or laws without the intervention of discretion in their application.").

117 F3d 579 (DC Cir 1997).

$\$$ Id at 584 (internal citations omitted).
} 
To phrase this another way, if an agency promulgates an overly vague regulation, a court could strike down subsequent "interpretations" on the ground that they create new law rather than simply state what the administrator thinks the law means. ${ }^{84}$

The Seventh Circuit's opinion in Hoctor $v$ United States Department of Agriculture ${ }^{85}$ demonstrates how this judicial check operates pursuant to Section 553-that is, how courts differentiate "interpretations" from "substantive rules" that must be promulgated according to notice and comment procedures. Pursuant to its statutory authority and the procedural requirements of the APA, the Department of Agriculture promulgated a "secure containment" regulation providing in part that facilities for housing animals "must be constructed of such material and of such strength as appropriate for the animals involved." quently, the Department issued an interpretation of this regulation requiring that dangerous animals be contained inside a perimeter fence at least eight feet high. ${ }^{87}$

The court held in Hoctor that the eight-foot height requirement was not an "interpretation" of any of the terms in the regulation: "There is no way to reason to an eight-foot perimeter-fence rule as opposed to a ... nine-foot fence or a ten-foot fence. None of these candidates for a rule is uniquely appropriate to, and in that sense derivable from, the duty of secure containment." tantly, the Department's "interpretation" created new obligations for animal dealers, because violation of the eight-foot requirement was grounds for sanction. ${ }^{89}$ Moreover, since the rule was essentially arbitrary, yet had material consequences for many animal dealers, those affected by the rule should have had the opportunity to suggest alternative heights. ${ }^{90}$ Given the specific na-

3ee American Hospital Association, 834 F2d at 1044-45.

82 F3d 165 (7th Cir 1996).

${ }^{86}$ Id at 167-68, citing 9 CFR $\$ 3.125$ (a).

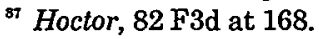

Id at 170 .

Id at 169.

${ }^{50}$ Id at 171 . There is also evidence that some Justices, while continuing to be committed to deference to agency interpretations of their own regulations, will be stricter about what they consider "interpretations." For example, in Thomas Jefferson University $v$ Shalala, 512 US 504 (1994), Justice Thomas, dissenting, argued that where a regulation merely expresses a general belief or intent, an agency should not be allowed to "interpret" substantive rules from it. Id at 519 (Thomas dissenting). The regulation at issue "praise[d] the benefits of approved educational programs and expresse[d] a belief that communities 'should' pay for such programs." Id. The Secretary interpreted this regulation to impose a restriction on the reimbursability of the costs of graduate medical education borne by a hospital's affiliated medical school. Id at 506 (majority opinion). Justice Thomas argued that by upholding the interpretation, "the Court disserves the very purpose behind the delegation of lawmaking power to administrative agencies, which is to 'resol[ve] ... ambi- 
ture of the "interpretation" relative to the more vague regulation, the court ruled that to uphold the "interpretation" would be to permit circumvention of the notice and comment procedures of the APA. ${ }^{91}$ Thus courts serve an important role in ensuring that agencies properly comply with the APA. Judicial review furthers Congress' intent to allow agencies to clarify their regulations easily while preventing agencies from abusing this authority.

2. Deference to agency interpretations of their own regulations violates separation of powers principles.

Some commentators also argue that deferring to an agency's interpretations of its own regulations violates separation of powers principles by allowing the same entity both to make the law and to construe it authoritatively. ${ }^{92} \mathrm{~A}$ similar argument has been made that Cheuron violates separation of powers by allowing agencies, rather than the courts, to "say what the law is." In response to claims that Chevron violates separation of powers, Judge Starr argues that under Chevron courts still fulfill their duty to "say what the law is." Under Chevron, a court's interpretive task is to determine the boundaries of an agency's rulemak-

guity in a statutory text." Id at 525 (Thomas dissenting) (internal citations omitted). Like the court in Hoctor, Thomas would have required the agency to issue a separate regulation under notice and comment.

2182 F3d at 172.

${ }^{22}$ See Manning, 96 Colum L Rev at 654 (cited in note 15) (concluding that "Seminole Rock contradicts the constitutional premise that lawmaking and law-exposition must be distinct'). See also Anthony, 10 Admin L J Am U at 9-11 (cited in note 80) (arguing that deference to agency interpretations of regulations violates $\S 706$ of the APA, which requires courts to "determine the meaning or applicability of the terms of an agency action"). Anthony does not discuss the underlying justifications for deference to agency interpretations of regulations; he is more concerned with the fact that in practice the Court has made these interpretations binding. Id at 4-5. For a response to Anthony's claim that deference violates $\$ 706$ of the APA, see Scalia, 1989 Duke L J at 514 (cited in note 8) (noting that it has never been the case, and was not the case when the APA was adopted, that agency interpretations are subject to plenary judicial review).

${ }^{33}$ See Manning, 96 Colum $L$ Rev at 621 (cited in note 15) ("Commentators have frequently observed that Chevron's concept of 'binding deference' is in apparent tension with the understanding, announced in Marbury $v$ Madison, that '[i]t is emphatically the province and duty of the judicial department to say what the law is."). See also Sunstein, 90 Colum L Rev at 2074 (cited in note 26) (noting that Chevron is "quite jarring" to those who believe that "it is for judges, and no one else, to 'say what the law is"). Sunstein goes on to argue that in many ways Chevron is consistent with the New Deal "reformation" in which the principles of "administrative autonomy and limited judicial interference with the process of regulation" became prominent. Id at 2081, 2119.

* Marbury v Madison, 5 US (1 Cranch) 137, 177 (1803). See Kenneth W. Starr, Judicial Review in the Post-Chevron Era, 3 Yale J Reg 283, 308-09 (1986). 
ing authority and further determine whether the rule promulgated fits within those bounds. ${ }^{95}$

The separation of powers argument seems stronger in the context of agency interpretations of their own regulations since in these cases not only is the agency exercising purportedly exclusive judicial power to say what the law is, but it is also construing law that it made. ${ }^{96}$ However, even here courts continue to play a role in interpreting law. Courts check an agency's power to interpret its own regulations by striking down overly vague regulations or purported "interpretations" that are in fact substantive rules or new law. Furthermore, courts may review regulations to ensure that, as interpreted, they carry out the terms of the statute ${ }^{97}$ Finally, courts retain the authority to review the application of law to facts. ${ }^{98}$ Since courts still play a role in construing the regulation, the governing statute, and the APA in deciding whether a given pronouncement is a valid interpretation, it is not the case that the agency is the law maker and the sole law interpreter.

Moreover, recall that when the agency promulgates an interpretation of its own regulation, it is in the same position as Congress when it passes a clarifying amendment. No one would argue that such congressional action usurps the courts' power to say what the law is. Because of an agency's expertise, political accountability, and unique relationship to the regulation, Congress intends for the agency, with limited interference from courts, to make needed clarifications to regulations and provide guidance to those regulated. Presuming that the authority to interpret the

${ }^{5}$ Starr, 3 Yale J Reg at 308-09 (cited in note 94) (arguing that Cheuron does not violate Marbury because a court retains the authority to decide whether that agency has been delegated interpretive authority and to determine whether that authority has been exercised arbitrarily or capriciously). Judge Starr builds off of the argument of Professor Monaghan. Id at 308, citing Henry P. Monaghan, Marbury and the Administrative State, 83 Colum L Rev 1 (1983). Professor Monaghan argued, prior to the Chevron decision, that deference to agency interpretations of a statute depends on whether substantive lawmaking authority has been delegated to the agency. Monaghan, 83 Colum L Rev at 6 .

${ }^{96}$ Professor Manning discusses the difference between deference to agency interpretations of regulations and deference to agency interpretations of statutes and concludes that deference under Cheuron does not violate separation of powers principles because it "retains one independent check on lawmaking by Congress," whereas when agencies interpret regulations they have promulgated, there is no independent interpretive check on lawmaking. Manning, 96 Colum L Rev at 639 (cited in note 15).

${ }^{97}$ See Foothill Presbyterian Hospital v Shalala, 152 F3d 1132, 1134 (9th Cir 1998) ("In reviewing an administrative agency's construction of a statute or regulations, we must reject constructions that are contrary to clear congressional intent or that frustrate the policy that Congress sought to implement.").

so Sniversal Camera Corp v NLRB, 340 US 474 (1951) (holding that agency adjudicatory decisions must be reviewed for substantial evidence). 
regulations it promulgates is a component of an agency's delegated policymaking authority is a rational reconstruction of congressional instructions. At the same time, courts retain an important role in ensuring that the agency stays within the bounds of its delegated authority and exercises that authority pursuant to the correct procedures.

The next Part demonstrates how the adoption of the Cheuron justification for deference to agency interpretations of regulations is useful in guiding courts when agencies set forth conflicting interpretations of the same regulation.

\section{APPLYING CHEVRON DEFERENCE TO INTERAGENCY DISPUTES OVER REGULATIONS}

There are several cases applying deference principles when one agency is interpreting another agency's regulation or statute. ${ }^{99}$ These are the easy cases. Chevron deference only applies to the statute the agency is charged with implementing. Another agency may need to interpret the statute from time to time, but Congress did not delegate policymaking authority under the statute to the other agency. ${ }^{100}$ Therefore, the second agency's interpretation is not entitled to deference.

The same reasoning holds if we apply Chevron deference to an agency's interpretation of a regulation promulgated and administered by another agency. Congress has delegated policymaking authority only to the promulgating agency, and that agency's interpretation should control. In these cases, moreover, even if the court defers based on the Seminole Rock justification for deference-agency expertise-it will defer to the agency that drafted and regularly implements the regulation. In most cases, this will be the same agency to which Congress has delegated policymaking authority. Therefore, whether the court adopts the

\footnotetext{
9 See, for example, Division of Military and Naval Affairs, State of New York $v$ Federal Labor Relations Authority, 683 F2d 45 (2d Cir 1982). The FLRA had interpreted the phrase "official business" in 5 USC $\$$ 5702(a) to include collective bargaining done on official time and on this basis held that the New York State Council was required to reimburse Union representatives for expenses incurred during contract negotiations with the New York National Guard. Id at 47. After finding that 5 USC $§ 5702(a)$ is not part of the FLRA's organic statute, the court held that "[n]o great deference is due an agency interpretation of another agency's statute." Id at 48 . See also Russell L. Weaver, Deference to Regulatory Interpretations: Inter-Agency Conflicts, 43 Ala L Rev 35, 39-41 (1991) (discussing cases where one agency has responsibility for establishing a regulatory scheme and another agency interprets that scheme).

${ }^{100}$ See General Electric Co $v$ Gilbert, 429 US 125, 141, 144-45 (1976) (holding that EEOC's interpretation of Title VII was not entitled to great deference because Congress "did not confer upon the EEOC authority to promulgate rules or regulations pursuant to that Title").
} 
Seminole Rock or the Chevron justification for deference, it will reach the same result.

Other cases are not as easy. This Part discusses these harder cases. In these cases, whether the court defers to the agency that it believes has greater expertise for determining the "correct" interpretation-as Seminole Rock suggests-or whether it defers to the agency to which it presumes Congress has delegated policymaking authority-as Chevron dictates-often will change the outcome. Moreover, these cases show that it is sometimes difficult to determine to which agency Congress intended to delegate policymaking authority. Each subpart shows how the underlying justification for deference that a court uses may change the decision in a case involving interagency conflict. Using the Chevron justification for deference endorsed in Part II, each subpart also demonstrates how courts should analyze these cases.

Subpart A looks at conflicts arising when rulemaking and adjudicatory functions for the administration of a single act are split between two agencies. Subpart B looks at cases in which rulemaking authority under an act has been transferred from one agency to another. Finally, Subpart $\mathrm{C}$ considers conflicts arising when two or more agencies share authority to implement an act.

\section{A. Conflicts Within the Split Enforcement Model}

Under the "Split Enforcement Model," rulemaking and adjudicatory functions for the administration of a single statute are split between two independent agencies. ${ }^{101}$ Thus, for example, the Occupational Safety and Health Act ("OSHA") gives the Secretary of Labor the power to set and enforce workplace health and safety standards and grants the Occupational Safety and Health Review Commission ("Commission") the responsibility to "carry out adjudicatory functions." ${ }^{\text {102 }}$ Shortly after OSHA was enacted, conflicts between the proper interpretation of OSHA and regulations promulgated thereunder arose between the Secretary and the Commission. ${ }^{103}$

\footnotetext{
${ }^{101}$ For a more detailed description of the Split Enforcement Model and its aims and problems, see George Robert Johnson, Jr., The Split-Enforcement Model: Some Conclusions from the OHSA and MSHA Experiences, 39 Admin L Rev 315 (1987).

${ }^{102}$ Martin, 499 US at 147 (describing the demarcation of responsibilities between Secretary of Labor and Commission). See also Occupational Safety and Health Act of 1970, 29 USC $\S 651$ et seq (1994).

${ }^{103}$ The uncertainty of which agency courts should defer to when the underlying justification for deference is not settled is illustrated in the circuit split that Martin addressed. See Brock v Bechtel Power Corp, 803 F2d 999, 1000 (9th Cir 1986) ("W]e will defer to the Commission's expertise ... because 'it is the Commission and not the Secretary which is charged with the final administrative adjudication of the Act."), citing Brennan v Occupa-
} 
In Martin, the Supreme Court held that when the Secretary and the Commission assert conflicting interpretations of a regulation, the Secretary's interpretation should control. ${ }^{104}$ The language of the opinion strongly suggests that the Court adopted the Chevron justification for deference in making its decision. The Court phrased the question before it as "to which administrative actor-the Secretary or the Commission-did Congress delegate this 'interpretive' lawmaking power under the OSH Act." ${ }^{105}$ A review of the legislative history of the Act revealed that Congress wanted only one actor to be ultimately responsible for policy decisions made to implement OSHA. ${ }^{106}$ The Court reasoned that if the power to promulgate rules was divided from the power to interpret them, policymaking authority would be split, contrary to what Congress intended. ${ }^{107}$ Because the Secretary was delegated the authority to make policy through rulemaking, it followed that he alone was delegated the authority to make policy through interpretations. ${ }^{108}$ Thus, in deciding which agency deserved deference, the Court looked to which agency Congress intended to delegate policymaking authority, consistent with the justification for deference set forth in Cheuron. ${ }^{109}$

Martin was decided consistently with the delegation principle elaborated in Part II. The rule in Martin, which is controlling in split-enforcement cases, is that, when agency interpretations of a regulation conflict, courts must defer to the agency to whom Congress has delegated policymaking authority. Because rulemaking necessarily involves policymaking, courts may presume that the agency to whom Congress has delegated rulemaking

tional Safety and Health Review Commission, 513 F2d 713, 715-16 (8th Cir 1975); Donovan $v$ A. Amorello \& Sons, Inc, 761 F2d 61, 65-66 (1st Cir 1985) (holding that in cases of conflict the Secretary deserves deference because Congress intended the Secretary, not the Commission, to have policymaking authority); Bethlehem Steel Corp v Occupational Safety and Health Review Commission, 573 F2d 157, 160 (3d Cir 1978) (holding that when the Secretary and the Commission offer conflicting interpretations of the same regulation neither deserves deference).

${ }^{104}$ Martin, 499 US at 152.

${ }^{106}$ Id at 151.

${ }^{106}$ Id at 153-54.

${ }^{107} \mathrm{Id}$.

${ }^{100}$ Id at 154.

${ }^{109}$ The Court presumed that Congress delegated policymaking authority to the Secretary because the Secretary had greater expertise. Id at 152-53. As noted in Part I, expertise influences to whom Congress initially chooses to delegate policymaking authority. The court defers not because the agency is more expert than the court, but because the court presumes that Congress intended the agency to make the necessary policy decision. See text accompanying notes $28-31$. This is a fine distinction that will continue to be relevant to the analysis in the sections that follow. 
authority is the chosen policymaker, unless the statute or legislative history clearly indicates otherwise.

However, Martin may have been resolved differently had the Court followed the Seminole Rock deference model and looked exclusively at relative competence. Under Seminole Rock, the Court may have determined that the Secretary and the Commission are equally expert, given their experiences and historical familiarity with implementing the regulation. In that scenario, the Court could side with the entity whose interpretation it found to be more in line with the Court's own view of the most reasonable interpretation.

\section{B. Transferred Jurisdiction}

As the federal government attempts to cut down on the size of the administrative state by dismantling duplicative agencies and concentrating authority over statutes concerning a similar subject matter in one agency, it sometimes transfers authority over a statute from one agency to another. ${ }^{110}$ These transfers can give rise to conflicting interpretations of the statute and regulations promulgated thereunder by the first agency.

In Pauley $v$ BethEnergy Mines, Inc, ${ }^{111}$ decided the same year as Martin, the Court held that when the agency initially responsible for the administration of a statute and the new agency offer conflicting interpretations of a regulation, courts must defer to the new agency's interpretation. The case demonstrates how the justification for deference that a court relies upon can be outcome determinative in cases where jurisdiction has been transferred from one agency to another. In Pauley, the authority to administer the black lung benefits program was first held by the Department of Health, Education, and Welfare ("HEW") and was later transferred to the Department of Labor ("DOL"). ${ }^{112}$ The authorizing statute provided that the "criteria applied by the Sec-

\footnotetext{
${ }^{110}$ See, for example, 22 USC § 6209(a)(1) (1994) (authorizing the President to transfer the responsibilities of the Board for International Broadcasting to the United States Information Agency, the Broadcasting Board of Governors, or the International Broadcast Bureau); Bragdon v Abbott, 118 S Ct 2196, 2203 (1998) (noting transfer, by President, of responsibility for the implementation and enforcement of Section 504 of the Americans with Disabilities Act from the Department of Health, Education, and Welfare to the Attorney General); EEOC v Delaware Department of Health and Social Services, 595 F Supp 568, 573 (D Del 1984) (upholding transfer of authority to enforce Equal Pay Act from the Secretary of Labor to the EEOC).

"1" 501 US 680 (1991).

${ }^{112}$ Id at 683 .
} 
retary of Labor ... shall not be more restrictive than the criteria applicable" under the interim HEW regulations. ${ }^{113}$

Relying on Martin and Chevron, the majority held that the Secretary of Labor's interpretation of the HEW regulations, and his position that the regulations were not more restrictive than HEW's, were entitled to deference. ${ }^{114}$ The Court stated, "The identification and classification of medical eligibility criteria necessarily require significant expertise and entail the exercise of judgment grounded in policy concerns. In those circumstances, courts appropriately defer to the agency entrusted by Congress to make such policy determinations." 15

The Court looked to whether Congress intended the Secretary to have policymaking authority within the regulatory scheme. Because Congress did not require the DOL to adopt the $\mathrm{HEW}$ interim regulations verbatim, the Court reasoned that Congress intended the Secretary of Labor to make his own policy judgments. ${ }^{116}$ Thus, in determining whether the Secretary's interpretation of the HEW regulations deserved deference, the Court adopted the Chevron justification for deference.

This rationale was adopted explicitly in Amerada Hess Pipeline Corp v Federal Energy Regulatory Commission. ${ }^{117}$ The regulations at issue in Amerada were promulgated by the Interstate Commerce Commission. Subsequently, authority over oil pipelines was transferred to FERC. ${ }^{18}$ The court held that FERC's interpretations of the regulations promulgated by ICC were entitled to deference because "deference is not accorded to agency interpretations merely because they possess a special expertise. Courts defer to agency interpretations in large part because Congress has chosen to delegate to the agency decisionmaking in the field." 119

Had the Court in Pauley relied on the Seminole Rock justification for deference, it might not have deferred to the Secretary's interpretation. Rather, it likely would have determined independently whether the Secretary's new regulations were more re-

\footnotetext{
${ }^{113} \mathrm{Id}$ at 695, citing 30 USC $\S 902(f)(2)$ (1994).

"' 501 US at 698 ("As delegated by Congress, then, the Secretary's authority to promulgate interim regulations 'not ... more restrictive than' the HEW interim regulations necessarily entails the authority to interpret HEW's regulations and the discretion to promulgate interim regulations based on a reasonable interpretation thereof. From this congressional delegation derives the Secretary's entitlement to judicial deference.").

${ }^{115}$ Id at 697.

"116 Id.

1117 F3d 596 (DC Cir 1997).

"118 Id at 600 .

${ }^{119}$ Id at 601.
} 
strictive than the HEW regulations. The drafter, HEW, had the requisite institutional memory of the meaning and intent of its regulations and also had experience implementing them, when it still had administrative responsibility. Since HEW was dismantled and its interpretation, consequently, was unavailable, the Court would have had to construe the regulations itself. Alternatively, the Court might have reasoned under the Seminole Rock model that the transferee agency is still more expert than the Court, and therefore deference to the transferee agency is appropriate. Such reasoning would raise a host of issues about the kind of expertise the transferee agency must possess to merit deference. Must an agency have promulgated a regulation to be an "expert" on the "correct" interpretation? Would the agency have sufficient expertise if implementing authority had only recently been transferred to it? A rule that when Congress transfers policymaking authority from one agency to another it intends for the new agency's policymaking authority to extend to the interpretation of regulations promulgated by the prior agency is more predictable and pragmatic. The new agency assumes all of the policymaking authority for the regulatory scheme. Moreover, the transferee agency should not be limited to prior interpretations inconsistent with its own policy judgments.

\section{Conflicts Arising out of Overlapping Jurisdiction}

There are a number of substantive areas in which Congress. has delegated regulatory power to more than one agency. For example, the Federal Trade Commission and the Department of Justice share responsibility for enforcing the antitrust laws; the National Labor Relations Board and the Secretary of Labor share responsibility for labor policy; and the Federal Drug Administration and the Department of Agriculture have overlapping jurisdiction over some labeling policies. ${ }^{120}$ These overlaps create the possibility of conflicting interpretations of the same statute or regulation. Moreover, they present the most difficulties for courts attempting to decide which agency interpretations, if any, should be given deference.

The D.C. Circuit was the first court to confront a conflict of overlapping jurisdiction. In Caiola $v$ Carroll, ${ }^{121}$ the appellants were debarred as government contractors under a regulation issued jointly by the Department of Defense, the General Services

\footnotetext{
${ }^{20}$ See Richard H. Pildes and Cass R. Sunstein, Reinventing the Regulatory State, $62 \mathrm{U}$ Chi L Rev 1, 28 (1995).

${ }^{121} 851$ F2d 395 (DC Cir 1988).
} 
Administration, and the National Aeronautics and Space Administration. ${ }^{122}$ The appellants argued, among other things, that Carroll, an agent of the Department of Defense, erroneously interpreted the phrase "reason to know" in the regulation. ${ }^{123}$ Relying on Cheuron, the D.C. Circuit held that while an agency's interpretations of its own regulations usually are entitled to "considerable deference," such deference is inappropriate when the regulation was written and promulgated by three separate agencies. ${ }^{124}$ "The diffusion of the interpretive authority among several agencies, and the possibility of inconsistent interpretations, weaken the case for deference." 125

In holding that deference was inappropriate, the Caiola court implicitly sought to reconstruct congressional intent as to whether the courts should defer to any agency when several agencies jointly promulgate and enforce a given regulation. The court determined that prudential concerns counseled against deference. The court feared that the agencies would interpret the regulations differently, leaving government contractors uncertain as to how to comply with the regulation. ${ }^{126}$ Moreover, the court may have felt it lacked guidance in deciding which agency deserved deference. The decision costs associated with this inquiry may have been too high compared to independently interpreting the regulation. Given these considerations, the court reasoned that Congress likely intended that the court be vested with interpretive authority. ${ }^{127}$

Had the Caiola court relied on the expertise principle of Seminole Rock instead of the delegation principle of Chevron, it is unclear that the case would have come out differently. However, the analysis would have been quite distinct. The court could have found that because the Department of Defense had not drafted the regulation alone, it had no special insight into the regulation's intended meaning and effect. ${ }^{128}$ In any particular case, however, deference would depend on the court's knowledge of the process by which the regulation was adopted. If the agency advocating the interpretation was responsible for the research and policy analysis underlying the regulation, or the agency had more experience with the subject matter, the agency's interpretation

\footnotetext{
${ }^{122}$ Id at 397.

${ }^{123}$ Id at 399.

${ }^{22} \mathrm{Id}$.

${ }^{12} \mathrm{Id}$.

${ }^{12} \mathrm{Id}$.

${ }^{12 \pi} \mathrm{Id}$.

${ }^{123}$ See Bethlehem Steel, 573 F2d at 160 . See also note 103 and accompanying text.
} 
could be entitled to greater deference. Under Seminole Rock, a court might let the interpretation bind the other agencies applying the regulation, countering the possibility of inconsistent interpretations.

The complexity of cases such as Caiola, in which overlapping jurisdiction must be resolved, suggests that the presumption articulated in Part II may need more refinement. While Chevron counsels courts to determine to which agency Congress has delegated policymaking authority, courts must remember that Chevron is only a presumption based on a rational reconstruction of congressional intent. In some circumstances, as the court found in Caiola, congressional intent may cut against deference.

In overlapping jurisdiction cases, there are two possible options: courts may adopt an across the board presumption that in cases of potentially inconsistent interpretations due to joint implementing authority, ${ }^{129}$ courts should not defer to any agency's interpretation of the regulation. ${ }^{130}$ Alternatively, courts may make a case-by-case determination whether in any particular case it is possible to defer to one agency's interpretation without risking inconsistent interpretations. Which path courts take may depend on individual judges' position in the debate over the relative merits of rules versus standards.

Consider Bowen $v$ American Hospital Association, ${ }^{131}$ involving one agency's interpretation of a statute under which many agencies had rulemaking authority. In a case such as this, a reasonable reconstruction of legislative instructions might point towards deference even if multiple agencies share policymaking authority. The portion of the Rehabilitation Act at issue in American Hospital Association authorized any head of an Executive Branch agency to promulgate regulations prohibiting discrimination

\footnotetext{
${ }^{129}$ Note that courts may want to guard against not only directly conflicting interpretations, but also interpretations that are slightly different and as such pose practical compliance problems. To take a simplified example, and one involving the implementation of a statute rather than a regulation, suppose one agency promulgates a regulation under Section 504 of the Rehabilitation Act of 1973 (the Act at issue in Bowen v American Hospital Association, discussed in the text accompanying notes 131-33) requiring two and one-half foot wide passageways to accommodate wheelchairs on airplanes and another agency promulgates a regulation requiring four-foot wide passageways to accommodate wheelchairs in national parks. These regulations do not directly conflict and both are within the agencies' statutory authority. However, it might be preferable to have standard width requirements so wheelchairs could be a standard size.

${ }^{130}$ See Weaver, $43 \mathrm{Ala}$ L Rev at 67 (cited in note 99) (observing that Cheuron and Martin provide insufficient guidance in cases of overlapping jurisdiction and that, therefore, courts should independently construe the meaning of the statute or regulation at issue).

${ }^{131} 476$ US 610 (1986).
} 
against the handicapped. ${ }^{132}$ The Court held that no agency's interpretation of the Act deserved deference because "there is [] not the same basis for deference predicated on expertise as we found [in Chevron]." "133 The Court reasoned that because Congress had not delegated exclusive policymaking authority under the Act to any one agency, there was no basis on which to presume that Congress wanted the Department of Health and Human Services' interpretation, in this case, to be controlling.

One could argue, however, that Congress intended for each agency to use its expertise, political accountability, and ability to respond to competing interests in its area of concern to make appropriate regulations, and, accordingly, had delegated to each agency precisely the authority to construe the (very general) statute within the agency's jurisdiction. Under this view, the Court should have deferred to HHS since its regulation concerned treatment of handicapped infants in hospitals, and, thus, HHS was acting within its sphere of delegated authority. ${ }^{134}$ If each agency is to act only within its area of concern and expertise, it is reasonable to infer a congressional delegation of interpretive authority to each agency. ${ }^{135}$

A rule that in such cases no deference is due any agency would decrease courts' decision costs and force Congress to legislate with this background rule in mind. If Congress wants an agency's policy choices to control, it can explicitly instruct the courts to defer. However, a case-by-case determination likely would lead to deference in many instances. As the example above illustrates, Congress sometimes sets a broad policy goal and then asks various agencies to help implement that goal in their discrete areas of regulatory control. Interpreting a regulation promulgated under such an act calls upon the same expertise, political

\footnotetext{
132 Id at 642.

${ }^{15}$ Id at $642 \mathrm{n} 30$.

${ }^{13}$ Even using this analysis, the Court would have found the Secretary's regulation an unreasonable regulation: "Even according the greatest respect to the Secretary's action, however, deference cannot fill the lack of an evidentiary foundation on which the Final Rules must rest." Id at 643.

${ }^{135}$ See, for example, KMart Corp $v$ Cartier, Inc, 486 US 281, 293 n 4 (1988) (suggesting that it may be appropriate for agency legislative rules to be based on varying interpretations of the same statutory phrase when the phrase is being applied in different contexts). Here again the subtle difference between deference to expertise and deference to legislative intent inferred (in part) from expertise arises. A court might find an implied congressional intent to delegate interpretive authority because of the agency's expertise in and familiarity with the area of health care. Because a court would be trying to find the best reconstruction of legislative intent, it could hold, as the court in Caiola held, that Congress intends the courts not to defer where interpretive authority is diffuse. Congressional intent would trump expertise.
} 
accountability, and ability to reconcile competing political interests that moved the Court to adopt the Chevron presumption of congressional intent to delegate. ${ }^{136}$ The case-by-case approach, therefore, seems to account better for how Congress at times delegates authority and furthers the presumption that Congress prefers agencies rather than courts to make necessary policy choices.

The discussion in this Part demonstrates that when conflicts arise within split enforcement schemes and when jurisdiction has been transferred, applying the Chevron justification for deference to agency interpretations of regulations is consistent with the Court's approach-as illustrated in Martin and Pauley. Thus, extending the Chevron justification for deference to interpretations of regulations not only is more theoretically defensible, as shown in Part II, but is supported by the Court's recent jurisprudence. This Part also shows why the subtle difference between Seminole Rock deference to expertise and Chevron deference to congressional delegation matters. Had the Court followed the reasoning in Seminole Rock in these cases, they may have come out differently, and predictability would have been sacrificed.

Cases of overlapping jurisdiction are more difficult to resolve using the Chevron model. In attempting to reconstruct congressional intent, courts are faced with competing concerns. On one side there are concerns with agencies promulgating conflicting interpretations. Moreover, determining whether Congress intended courts to defer to one agency over another may be an inefficient use of judicial resources. On the other side is the acknowledgment that Congress delegated implementing authority to these agencies and is relying on their policy choices for sound reasons. The advantage of Chevron in this context is that it focuses a court's attention on the right question: What is the best reconstruction of congressional intent in these circumstances? ? $^{137}$

\section{CONCLUSION}

In Chevron, the Court adopted a new, more constitutionally legitimate justification for deference to an agency's interpretations of its organic statutes: because resolution of statutory ambiguities often involves policy determinations, courts should pre-

\footnotetext{
${ }^{136}$ See text accompanying notes 28-30.

${ }^{137}$ Professor Sunstein phrases the issue in similar terms. See Sunstein, 90 Colum L Rev at 2086 (cited in note 26) ("[T] he court's task is to make the best reconstruction that it can of congressional instructions. And if Congress has not made a clear decision one way or the other, the choice among the alternatives will call for an assessment of which strategy is the most sensible one to attribute to Congress under the circumstances.").
} 
sume that Congress has intended that the agency, and not the courts, make this policy choice. The Chevron justification for deference should replace Seminole Rock, the Court's prior justification for deference to agency interpretations of regulations, which was based solely on an assessment of relative institutional competence.

The Cheuron justification for deference will lead courts to better results in cases in which there are interagency conflicts in interpreting agency promulgated regulations. Courts should focus their attention on determining to which agency Congress intended to delegate policymaking authority. In split-enforcement and transferred jurisdiction cases, this analysis is both consistent with precedent and premised on a more constitutionally justifiable theory than Seminole Rock deference. Moreover, in the harder cases of overlapping jurisdiction, applying the Cheuron rationale will focus courts' attention on reconstructing implicit congressional instructions, thereby leading to more straightforward discussions of when and why courts should defer. 


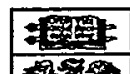

